\title{
Phylogenetic analysis of rabies viruses isolated from cattle in southern Brazil
}

\author{
Marcélia Emanuele S. Fernandes ${ }^{1}$ • Pedro Carnieli Jr. ${ }^{1}$ - Adriele N. F. Gregório ${ }^{1}$ Juliana G. C. Kawai ${ }^{1}$. \\ Rafael N. Oliveira ${ }^{1}$ - Laura L. Almeida ${ }^{2}$. Julio C. A. Rosa ${ }^{2} \cdot$ José C. Ferreira $^{2} \cdot$ Sandra D. Traverso $^{3} \cdot$ Paulo M. Roehe $^{4}$. \\ Helena B. C. R. Batista' ${ }^{1}$
}

Received: 18 July 2019 / Accepted: 2 January 2020 / Published online: 18 January 2020

(c) Springer Science+Business Media, LLC, part of Springer Nature 2020

\begin{abstract}
Bats and dogs are the main reservoirs of rabies virus (RABV) in Latin America and are responsible for the maintenance of different cycles of infection. In the two neighbour and most southern Brazilian states of Rio Grande do Sul (RS) and Santa Catarina (SC), rabies in dogs has been successfully controlled for more than 30 years. However, rabies associated to the rural cycle remains endemic, with a significant, though oscillating — annual incidence of rabies in cattle. Despite the plethora of studies on genetic analyses of Brazilian RABV, isolates from southern Brazil have only scarcely been investigated. This work was performed to identify the genetic lineages of RABVs circulating in states of RS and SC. Fifty-nine RABV cattle isolates from RS and SC were selected and submitted to reverse transcription/polymerase chain reaction (RT-PCR) followed by sequencing of the nucleoprotein gene. In RS, the circulation of two sublineages (1A and 1B) of RABV was detected, both with characteristics of lineages usually detected in vampire bats (Desmodus rotundus). In SC, only one sublineage of RABV (1B) was detected. Nevertheless, the findings reported here are expected to contribute to the understanding of the biology of the virus in the region and its interactions with the natural host $D$. rotundus.
\end{abstract}

Keywords Rural rabies · Genetic lineages $\cdot$ Rio Grande do Sul $\cdot$ Santa Catarina $\cdot$ Brazil

\section{Introduction}

Rabies is a fatal zoonosis associated with encephalitis in all mammals that is transmitted predominantly by bites from infected animals. The disease is caused by rabies virus (RABV), formally Rabies lyssavirus, the prototype of the genus Lyssavirus within the family Rhabdoviridae [1]. This is the only lyssavirus so far identified in Brazil [2].

\section{Edited by Zhen F. Fu.}

\section{Helena B. C. R. Batista \\ batistahbcr@gmail.com \\ Pasteur Institute, São Paulo, SP, Brazil \\ 2 Instituto de Pesquisas Veterinárias Desidério Finamor, Eldorado do Sul, RS, Brazil}

3 Laboratório de Patologia Animal, Universidade do Estado de Santa Catarina (LAPA/UDESC), Lages, SC, Brazil

4 Universidade Federal do Rio Grande do Sul (UFRGS), Porto Alegre, RS, Brazil
Rabies virus is present on all continents except Antarctica [3]. In Brazil, the infection is endemic and is maintained in the "aerial, sylvatic and rural" cycles, where bats are the main reservoirs. In some regions of the country, such as the northeast and northern regions, the urban cycle, with domestic dogs as reservoirs, is still maintained [4]. In the states of Rio Grande do Sul (RS) and Santa Catarina (SC), the most southern Brazilian states, urban rabies has not been detected since the 1980s [5, 6]. Nevertheless, vampire bats of the species Desmodus rotundus, remain as the natural reservoirs of the virus. As D. rotundus preferably feeds on cattle, the endemic character of rabies in cattle is maintained, giving rise to sporadic outbreaks of the disease. Despite the implementation of methods of control, such as reductions in vampire bat populations, vaccination of cattle (though not compulsory) and efforts to improve public awareness on the subject, the endemic status of the infection is maintained, with the occurrence of occasional, often yearly, outbreaks of disease. Such occurrences cause significant burdens to farmers due to the loss of livestock, in addition to causing serious risks of human contamination. 
It has been possible to associate different genetic lineages of RABV with the geographic distribution of the isolates $[7,8]$. Such association is important to study the routes of dissemination of the virus. Moreover, the association of particular RABV genetic lineages and the migratory profile of vampire bats may provide useful information in predicting future outbreaks of the disease. Therefore, analyses of genetic lineages of RABV could enable significant advances in the understanding of the epidemiology of infection within a particular region. Here, to investigate the genetic lineages of RABV circulating in RS and SC, phylogenetic analyses of the nucleoprotein gene $(N)$ of RABV were performed on isolates recovered from infected cattle.

\section{Materials and methods}

\section{Viruses}

Fifty-nine RABV isolates were collected between 2012 and 2015 . Viruses that were recovered from fragments of tissues of the central nervous system (CNS) of cattle from the states of RS and SC were analysed in the present study (Table 1). The sequences generated in this work were deposited and inspected by GenBank staff and registered as shown in Table 1 (www.ncbi.nlm.nih.gov/genbank/). Routine identification of rabies virus antigens was performed with the direct fluorescent antibody test (DFAT), following standard diagnostic procedures [9]. The isolates included in this study

Table 1 Origin of Rabies lyssavirus (RABV) sequenced and examined in the present study Identification (GenBank accession numbers) and localization (Municipality and State)

\begin{tabular}{|c|c|}
\hline Identification of samples & Localization \\
\hline $\begin{array}{l}\text { KX090643.1; KX090642.1; KX090641.1; KX090640.1; KX090639.1; KX090638.1; KX090637.1; KX090636.1; } \\
\text { KX090635.1 }\end{array}$ & Pinhal Grande/RS \\
\hline KX090625.1; KX090629.1; KX090612.1 & Camaquã/RS \\
\hline KX090626.1; KX090614.1; KX090613.1 & Rio Pardo/RS \\
\hline KX090627.1; KX090619.1 & Mariana Pimentel/RS \\
\hline KX090615.1 & São Jerônimo/RS \\
\hline KX090628.1; KX090603.1; KX090604.1; KX090605.1; KX090631.1; KX090632.1 & Gravataí/RS \\
\hline KX090611.1 & Porto Vera Cruz/RS \\
\hline KX090608.1 & Morro Redondo/RS \\
\hline KX090596.1 & Barra do Ribeiro/RS \\
\hline KX090602.1; KX090601.1; KX090618.1 & Glorinha/RS \\
\hline KX090599.1 & Canguçu/RS \\
\hline KX090600.1 & Esperança do Sul/RS \\
\hline KX090594.1; KX090633.1 & Arroio Grande/RS \\
\hline KX090607.1 & Herveiras/RS \\
\hline KX090634.1 & São Paulo das Missões/RS \\
\hline KX090620.1 & Sapiranga/RS \\
\hline KX090595.1 & Arroio do Tigre/RS \\
\hline KX090609.1 & Novo Hamburgo/RS \\
\hline KX090621.1; KX090598.1; KX090597.1 & Candelária/RS \\
\hline KX090630.1; KX090623.1; KX090622.1 & Hulha Negra/RS \\
\hline KX090617.1; KX090616.1 & Viamão/RS \\
\hline KX090610.1 & Pedro Osório/RS \\
\hline KX090624.1 & Bagé/RS \\
\hline KX090585.1 & Leoberto Leal/SC \\
\hline KX090586.1 & Unknown/SC \\
\hline KX090589.1; KX090588.1; KX090587.1 & Anitápolis/SC \\
\hline KX090590.1 & São Bonifácio/SC \\
\hline KX090591.1 & São Martinho/SC \\
\hline KX090593.1; KX090592.1 & Rio Fortuna/SC \\
\hline
\end{tabular}

All samples were isolated from Central Nervous System (CNS) of cattle

$R S$ State of Rio Grande do Sul, SC State of Santa Catarina 
were selected by its availability at the Reference Laboratory for diagnosis of rabies in the state of RS (Instituto de Pesquisas Veterinárias Desidério Finamor-IPVDF) and in the Laboratory of Animal Pathology of University of State of Santa Catarina. This work complies with Protocol no. 01/2015 issued by the Ethics Committee of the Pasteur Institute, São Paulo.

\section{RT-PCR and sequencing}

Total RNA was extracted from infected brain tissues with TRIzol (Thermo Fisher Scientific ${ }^{\mathrm{TM}}$ ), according to manufacturer's instructions. cDNA synthesis of the genomic RNA and PCR amplifications were performed with primers that target the nucleoprotein gene $(N)$ of RABV: sense primer JW12 (5'-ACGCTTAACAACAARATCARAG-3') and antisense primer 304 (5'-TTGACGAAGATCTTGCTCAT-3') as previously described $[10,11]$. Viral RNA $(3-5 \mathrm{mg})$ was reverse-transcribed using 15 units of RevertAid Premium reverse transcriptase (Thermo Fisher Scientific ${ }^{\mathrm{TM}}$ ) and amplified by PCR using Taq DNA polymerase (Thermo Fisher Scientific ${ }^{\mathrm{TM}}, 5$ units $\left./ \mathrm{ml}\right)$ in PCR buffer $(1.5 \mathrm{mM}$ $\mathrm{MgCl}_{2}, 50 \mathrm{mM} \mathrm{KCl}, 20 \mathrm{mM}$ Tris-HCl, pH 8, $200 \mathrm{mM}$ each $\mathrm{dNTP}$ ) in a final volume of $50 \mu \mathrm{l}$. Thermal cycling conditions were as follows: 1 cycle at $94{ }^{\circ} \mathrm{C}$ for $5 \mathrm{~min} ; 35$ cycles at $94{ }^{\circ} \mathrm{C}$ for $45 \mathrm{~s}, 55^{\circ} \mathrm{C}$ for $45 \mathrm{~s}$ and $72{ }^{\circ} \mathrm{C}$ for $2 \mathrm{~min}$, followed by 1 final incubation at $72{ }^{\circ} \mathrm{C}$ for $10 \mathrm{~min}$. The amplicons obtained were purified with GFX ${ }^{\mathrm{TM}}$ PCR DNA and Gel Band Purification kit (GE Healthcare ${ }^{\mathrm{TM}}$ ) and sequenced with 3,2 pmol same primers used for PCR and BigDye Terminator v3.1Cycle Sequencing Kit (Thermo Fisher Scientific ${ }^{\mathrm{TM}}$ ). Extracts from mice infected with the "fixed" strain Challenge Virus Standard (CVS-31) were included in all reactions as positive controls. DEPC-treated water was included as negative control throughout.

\section{Phylogenetic analysis}

The RABV sequences obtained were edited with the CHROMAS software (version 2.24 Copyright@ $1998-2004$ Technelysium Pty Ltd.). Homology analyses were performed with basis on RABV sequences obtained at this work (59 sequences) and sequences available at the GenBank database as shown in Table 2 (64 sequences, including 56 sequences with genetic lineages from vampire bat $D$. rotundus, isolated from different regions of Brazil and other countries from Latin America, and 4 sequences corresponding to genetic lineages of RABV of nonhematophagous bats and 4 sequences of the genetic lineage of domestic dogs). Fig. 1 shows the geographical distribution of samples of RABV included in this study. A total of 123 nucleotide sequences of the RABV $N$ gene were included in the phylogenetic analyses. Sequences were aligned with CLUSTAL/W using the
BioEdit software version 7.1.3.0 [12] and the phylogenetic tree was performed by the Maximum Likelihood method based on the Tamura-Nei model [13], with MEGA 7 software [14]. A total of 1.218 nucleotides of the coding region of the RABV $N$ gene, nucleotide positions 202-1420 (amino acids $45-450$ in the PV strain of RABV-GenBank accession number: GB M13215.1) were analysed.

\section{Results}

\section{Sequencing and phylogenetic analysis}

A phylogenetic tree was constructed utilizing the 59 RABV isolates sequenced in this work. Another 64 RABV sequences recovered from GenBank were also included in the constructed tree (Fig. 2). Three clusters were formed: cluster 1 corresponded to sequences of viruses recovered from vampire bats; cluster 2 corresponded to sequences originating from nonhaematophagous bats and cluster $3 \mathrm{com}-$ prised sequences recovered from canids. Moreover, cluster 1 (vampire bats) could be further split into two subclusters: $1 \mathrm{~A}$, which included 37 isolates from RS, and $1 \mathrm{~B}$, which included 13 isolates from RS plus the 9 isolates from SC examined in this study.

\section{Identification of sublineages of RABV}

Subcluster 1A included, in addition to isolates from RS, a number of isolates from other regions of Brazil (the Southeast and North) and from Ecuador. In subcluster 1B along with isolates from RS and $\mathrm{SC}$, sequences corresponding to viruses recovered from GenBank isolated from Uruguay and Argentina were grouped together.

These findings reveal at least two sublineages (1A and 1B) of RABV circulating in RS, for which the main reservoir is the vampire bat $D$. rotundus. Sublineage $1 \mathrm{~A}$ seems to have a wider geographic distribution than sublineage 1B in RS, as $1 \mathrm{~A}$ was identified in the state's northern, eastern, southern and central regions. Sublineage 1B appears to have a more restricted geographic distribution, since representatives of this sublineage were recovered only in the northern and eastern regions of the state. Cocirculation of the two sublineages in the same region was detected in two municipalities (Gravataí and Glorinha, Eastern RS; Fig. 3a).

In the state of SC, only sublineage 1B was identified; however, the number of municipalities from which samples were available for this study were somewhat limited, including three in the southern area of the state (the municipalities of Rio Fortuna, São Martinho and São Bonifácio) and two in the eastern area of the state (the municipalities of Anitápolis and Leoberto Leal) (Fig. 3b). 
Table 2 Description of sequences of Rabies lyssavirus (RABV) recovered from GenBank (GB) and used in phylogenetic analysis (GenBank accession numbers, animal origin, localization, year, genetic lineage identified and reference)

\begin{tabular}{|c|c|c|c|c|c|}
\hline GB accession numbers & Animal origin & Localization & Year & Genetic lineage identified & Reference \\
\hline GU552789 & Molossus molossus & Brazil & 2006 & Lineage 2 & Oliveira et al. [15] \\
\hline GU552796 & Molossus sp. & Brazil & 2007 & Lineage 2 & Oliveira et al. [15] \\
\hline AB201815 & Molossus molossus & Brazil & 2005 & Lineage 2 & Kobayashi et al. [7] \\
\hline AB201818 & Molossus sp. & Brazil & 2005 & Lineage 2 & Kobayashi et al. [7] \\
\hline AB685222 & Cattle & RS/Brazil & 2016 & Lineage 1 sublineage $1 \mathrm{~A}$ & Itou et al. [16] \\
\hline AB685226 & Cattle & RS/Brazil & 2016 & Lineage 1 sublineage $1 \mathrm{~A}$ & Itou et al. [16] \\
\hline EF152264 & Canids & Brazil & 2005 & Lineage 3 & Carnieli et al. [17] \\
\hline EF152275 & Canids & Brazil & 2005 & Lineage 3 & Carnieli et al. [17] \\
\hline EF152279 & Canids & Brazil & 2005 & Lineage 3 & Carnieli et al. [17] \\
\hline EF152280 & Canids & Brazil & 2005 & Lineage 3 & Carnieli et al. [17] \\
\hline EF363727 & Human & Ecuador & 2005 & Lineage 1 sublineage $1 \mathrm{~A}$ & Castilho et al. [18] \\
\hline EF363728 & Human & Ecuador & 2005 & Lineage 1 sublineage $1 \mathrm{~A}$ & Castilho et al. [18] \\
\hline EF363745 & Human & PA/Brazil & 2004 & Lineage 1 sublineage 1B & Castilho et al. [18] \\
\hline EF363748 & Human & PA/Brazil & 2004 & Lineage 1 sublineage $1 \mathrm{~B}$ & Castilho et al. [18] \\
\hline EF363751 & Human & PA/Brazil & 2004 & Lineage 1 sublineage $1 \mathrm{~A}$ & Castilho et al. [18] \\
\hline EF363755 & Human & PA/Brazil & 2005 & Lineage 1 sublineage $1 \mathrm{~A}$ & Castilho et al. [18] \\
\hline EF363756 & Human & PA/Brazil & 2005 & Lineage 1 sublineage $1 \mathrm{~A}$ & Castilho et al. [18] \\
\hline EF363757 & Human & PA/Brazil & 2005 & Lineage 1 sublineage $1 \mathrm{~A}$ & Castilho et al. [18] \\
\hline EF428576 & D. rotundus & $\mathrm{RJ} /$ Brazil & 2010 & Lineage 1 sublineage $1 \mathrm{~A}$ & Vieira et al. [19] \\
\hline EF428577 & D. rotundus & $\mathrm{RJ} /$ Brazil & 2010 & Lineage 1 sublineage $1 \mathrm{~A}$ & Vieira et al. [19] \\
\hline EF428578 & D. rotundus & $\mathrm{RJ} /$ Brazil & 2010 & Lineage 1 sublineage $1 \mathrm{~A}$ & Vieira et al. [19] \\
\hline EF428579 & D. rotundus & $\mathrm{RJ} /$ Brazil & 2010 & Lineage 1 sublineage $1 \mathrm{~A}$ & Vieira et al. [19] \\
\hline EF428580 & D. rotundus & $\mathrm{RJ} /$ Brazil & 2010 & Lineage 1 sublineage $1 \mathrm{~A}$ & Vieira et al. [19] \\
\hline EU981923 & Horse & Uruguay & 2008 & Lineage 1 sublineage 1B & Guarino et al. [20] \\
\hline EU981925 & Cattle & Uruguay & 2008 & Lineage 1 sublineage $1 \mathrm{~B}$ & Guarino et al. [20] \\
\hline EU981926 & Cattle & Uruguay & 2008 & Lineage 1 sublineage 1B & Guarino et al. [20] \\
\hline EU981927 & Cattle & Uruguay & 2008 & Lineage 1 sublineage $1 \mathrm{~B}$ & Guarino et al. [20] \\
\hline EU981928 & Cattle & Uruguay & 2008 & Lineage 1 sublineage 1B & Guarino et al. [20] \\
\hline EU981929 & Cattle & Uruguay & 2008 & Lineage 1 sublineage 1B & Guarino et al. [20] \\
\hline EU981930 & D. rotundus & Uruguay & 2007 & Lineage 1 sublineage 1B & Guarino et al. [20] \\
\hline EU981931 & D. rotundus & Uruguay & 2007 & Lineage 1 sublineage $1 \mathrm{~B}$ & Guarino et al. [20] \\
\hline GQ160921 & Cattle & MG/Brazil & 2007 & Lineage 1 sublineage $1 \mathrm{~A}$ & Macedo et al. [21] \\
\hline GQ160956 & Cattle & MG/Brazil & 2007 & Lineage 1 sublineage $1 \mathrm{~A}$ & Macedo et al. [21] \\
\hline GQ160917 & Cattle & MG/Brazil & 2007 & Lineage 1 sublineage $1 \mathrm{~A}$ & Macedo et al. [21] \\
\hline GQ160910 & Cattle & MG/Brazil & 2007 & Lineage 1 sublineage $1 \mathrm{~A}$ & Macedo et al. [21] \\
\hline GQ160918 & Cattle & MG/Brazil & 2007 & Lineage 1 sublineage $1 \mathrm{~A}$ & Macedo et al. [21] \\
\hline GQ160927 & Cattle & MG/Brazil & 2008 & Lineage 1 sublineage $1 \mathrm{~A}$ & Macedo et al. [21] \\
\hline GQ160928 & Cattle & MG/Brazil & 2008 & Lineage 1 sublineage $1 \mathrm{~A}$ & Macedo et al. [21] \\
\hline GQ160936 & Cattle & MG/Brazil & 2008 & Lineage 1 sublineage $1 \mathrm{~A}$ & Macedo et al. [21] \\
\hline GQ160946 & Cattle & SP/Brazil & 2008 & Lineage 1 sublineage $1 \mathrm{~A}$ & Macedo et al. [21] \\
\hline GQ160923 & Cattle & SP/Brazil & 2008 & Lineage 1 sublineage $1 \mathrm{~A}$ & Macedo et al. [21] \\
\hline GQ160924 & Horse & SP/Brazil & 2008 & Lineage 1 sublineage $1 \mathrm{~A}$ & Macedo et al. [21] \\
\hline GQ160944 & Cattle & SP/Brazil & 2008 & Lineage 1 sublineage $1 \mathrm{~A}$ & Macedo et al. [21] \\
\hline GQ160931 & Horse & SP/Brazil & 2008 & Lineage 1 sublineage $1 \mathrm{~A}$ & Macedo et al. [21] \\
\hline GQ160941 & Cattle & SP/Brazil & 2008 & Lineage 1 sublineage $1 \mathrm{~A}$ & Macedo et al. [21] \\
\hline GQ160916 & Cattle & SP/Brazil & 2008 & Lineage 1 sublineage $1 \mathrm{~A}$ & Macedo et al. [21] \\
\hline GQ160922 & Horse & SP/Brazil & 2008 & Lineage 1 sublineage $1 \mathrm{~A}$ & Macedo et al. [21] \\
\hline GQ160935 & Horse & SP/Brazil & 2008 & Lineage 1 sublineage $1 \mathrm{~A}$ & Macedo et al. [21] \\
\hline GQ160912 & Cattle & SP/Brazil & 2008 & Lineage 1 sublineage $1 \mathrm{~A}$ & Macedo et al. [21] \\
\hline
\end{tabular}


Table 2 (continued)

\begin{tabular}{llllll}
\hline GB accession numbers & Animal origin & Localization & Year & Genetic lineage identified & Reference \\
\hline GQ160919 & Cattle & SP/Brazil & 2008 & Lineage 1 sublineage 1A & Macedo et al. [21] \\
GQ160952 & Cattle & SP/Brazil & 2008 & Lineage 1 sublineage 1A & Macedo et al. [21] \\
GQ160954 & Cattle & SP/Brazil & 2008 & Lineage 1 sublineage 1A & Macedo et al. [21] \\
GQ160957 & Cattle & SP/Brazil & 2008 & Lineage 1 sublineage 1A & Macedo et al. [21] \\
GQ160958 & Cattle & SP/Brazil & 2008 & Lineage 1 sublineage 1A & Macedo et al. [21] \\
KF864327 & Cattle & Argentina & 2006 & Lineage 1 sublineage 1B & Macedo et al. [21] \\
KF864328 & Cattle & Argentina & 2006 & Lineage 1 sublineage 1B & Torres et al. [22] \\
KF864329 & Cattle & Argentina & 2006 & Lineage 1 sublineage 1B & Torres et al. [22] \\
KF864330 & Cattle & Argentina & 2006 & Lineage 1 sublineage 1B & Torres et al. [22] \\
KF864331 & Cattle & Argentina & 2006 & Lineage 1 sublineage 1B & Torres et al. [22] \\
KF864332 & Cattle & Argentina & 2006 & Lineage 1 sublineage 1B & Torres et al. [22] \\
KF864379 & Cattle & Argentina & 2006 & Lineage 1 sublineage 1A & Torres et al. [22] \\
KF864386 & Cattle & Argentina & 2006 & Lineage 1 sublineage 1A & Torres et al. [22] \\
KF864397 & Cattle & Argentina & 2006 & Lineage 1 sublineage 1A & Torres et al. [22] \\
KF864407 & Cattle & Argentina & 2006 & Lineage 1 sublineage 1A & Torres et al. [22] \\
\hline
\end{tabular}

$R S$ State of Rio Grande do Sul, PA State of Pará, RJ State of Rio de Janeiro, MG State of Minas Gerais, SP State of São Paulo

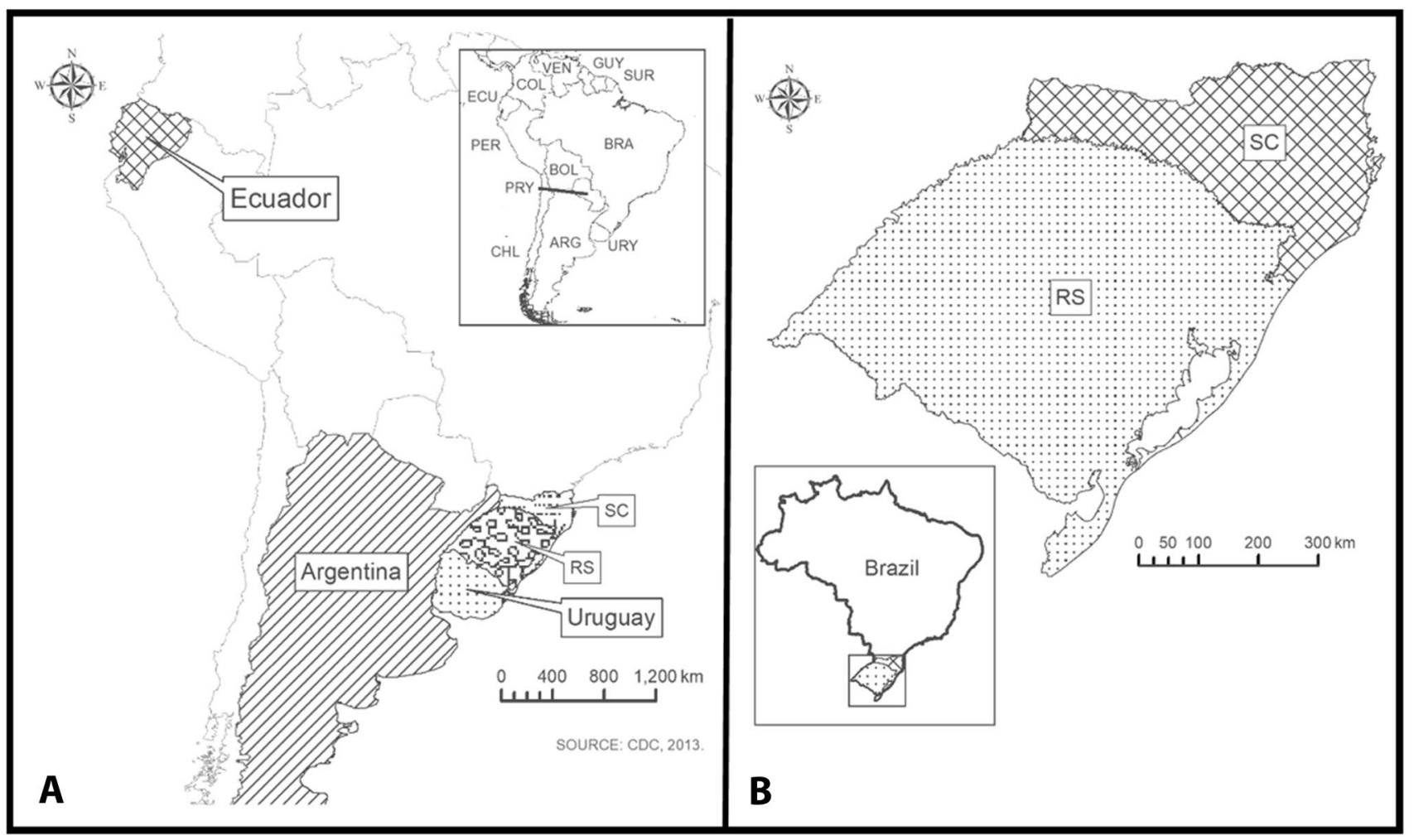

Fig. 1 Geographical distribution of samples of rabies virus (RABV) included in this study, a Map of Latin America showing countries where sequences of RABV were collected, $\mathbf{b}$ Map of Brazil showing each state where RABV isolates were collected and sequenced in this study

\section{Discussion}

Vampire bats of the species $D$. rotundus are distributed throughout Latin America [2]. However, the introduction and dissemination of cattle in the subcontinent have provided a widely available source of food for the species. The states of RS and SC, the two most southern states in Brazil, 
Fig. 2 Phylogenetic tree based on the partial 1.218-nt region within the N gene of RABV (nucleotide position 202-1420 in the standard sample of RABV PV-Pasteur Virus, GenBank accession number: GB M13215.1). Tree was generated by using Maximum Likelihood method based on the Tamura-Nei model (Tamura et al. 1993), with MEGA 7 software (Kumar et al. 2001). Cluster 1 (divided in subcluster $1 \mathrm{~A}$, marked in red and $1 \mathrm{~B}$, marked in blue), cluster 2 marked in green and cluster 3 marked in light blue. Samples sequenced in this study are marked with $* \mathrm{RS}$ and $* * \mathrm{SC}$

have been successful in controlling urban rabies transmitted by dogs. However, rural rabies remains endemic, mostly affecting cattle, since the species is the preferred food source for D. rotundus. Vaccination of cattle against rabies is not compulsory as the disease often occurs in outbreaks; farmers sometimes prefer not to vaccinate with the expectation that "there will be no rabies" on that particular season or year. Consequently, new outbreaks of rabies in cattle can be expected to occur and are invariably associated with the presence of infected vampire bats in the region. However, more detailed studies aiming to investigate the genetic lineages of RABV that may be circulating in southern Brazil are scarce [16, 23-25]. In view of this scarcity, in the present study, the coding region sequences of the RABV $N$ gene from isolates recovered from infected cattle in the states of RS and SC were sequenced and compared to equivalent sequences available in GenBank. Such an approach has been used in a number of previous studies $[7,8,21,23$, 24]. Through examination of the topology of the phylogenetic tree generated by the analyses, two genetic sublineages of RABV (1A and $1 \mathrm{~B}$ ) were identified to be circulating in southern Brazil, both having the vampire bat $D$. rotundus as their natural reservoir.

Indeed, the distributions of the isolates examined here do not reflect statistically representative samplings of all geographic areas of these two states. However, the sampling covered regions with high incidences of rabies in cattle. A few other studies have addressed the same issue; however, in those studies, sampling was performed in quite limited regions $[16,21,25]$. Therefore, available data on RABV sequences circulating in those regions are still quite scarce.

The current study identified RABV isolates of two sublineages $(1 \mathrm{~A}$ and $1 \mathrm{~B})$ that have been invariably associated with transmission by the vampire bat $D$. rotundus. Sublineage $1 \mathrm{~A}$ was more widely distributed than $1 \mathrm{~B}$ and was detected in all RS regions sampled. This sublineage clustered with RABV isolates from regions in northeast and central RS obtained in previous studies [16, 24]; the same sublineage has also been detected in southeastern Brazil (in the states of São Paulo, Rio de Janeiro and Minas Gerais), northern Brazil (in the State of Pará), Argentina and Ecuador, evidencing its wide geographic distribution. Sublineage $1 \mathrm{~B}$, in contrast, seemed to have a more restricted geographic distribution, since it was detected

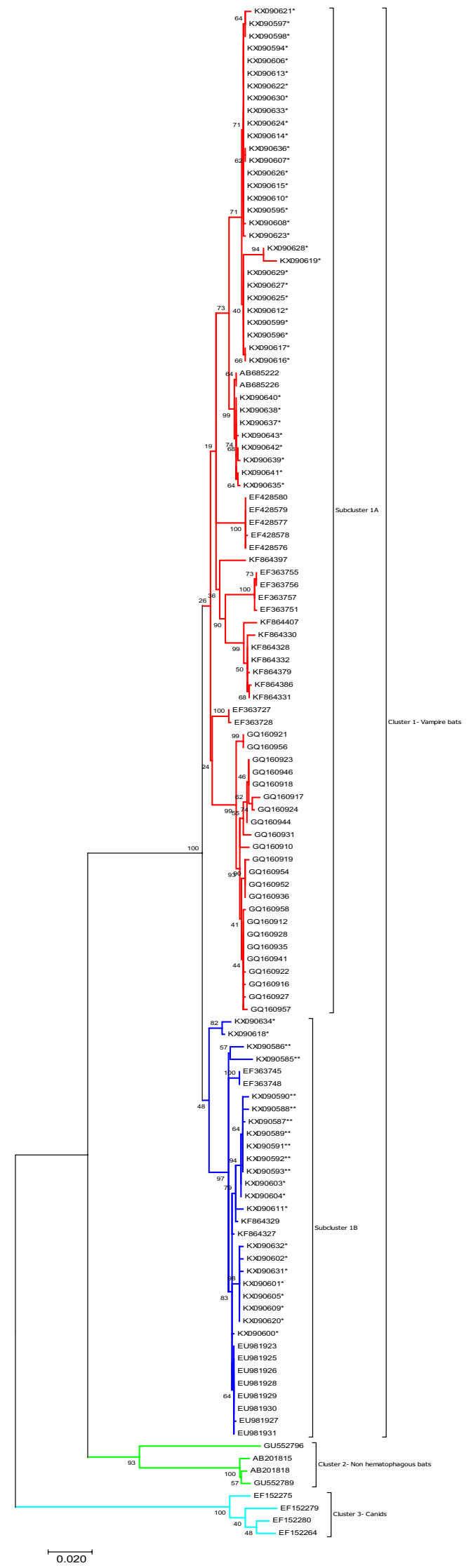




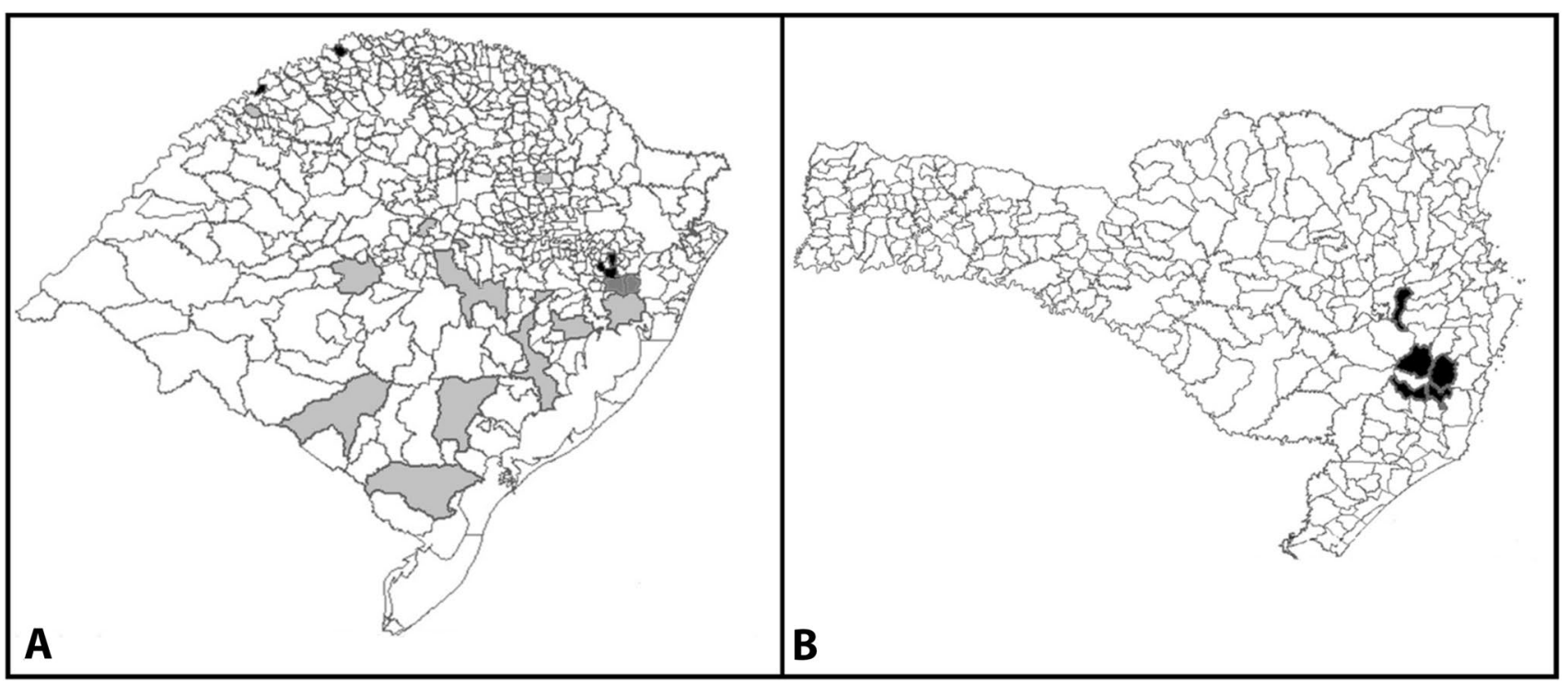

Fig. 3 Map of State of Rio Grande do Sul (a) and State of Santa Catarina (b) from southern Brazil showing locality of municipalities according to the sublineage of Rabies lyssavirus (RABV) identified.
Light grey indicates RABV sublineage 1A, black indicates sublineage $1 \mathrm{~B}$ and dark grey indicates municipalities where both sublineages $1 \mathrm{~A}$ and $1 \mathrm{~B}$ are identified only in the states of RS and SC, the two most southern states in Brazil, and in Argentina and Uruguay, countries bordering southern Brazil. This is the only sublineage identified in the state of SC.

The sublineages identified in the study could have originated from two different colonies of $D$ rotundus if independent coevolution occurred between each specific colony of bats and RABV. The geographic distribution of each viral sublineage may be related to the ecology of D. rotundus, which is able to move over long distances; such ecology is hypothesized to have contributed to the formation of the two sublineages of RABV.

In the present study, the analyses were focused on the $N$ gene due to the large number of sequences of such genes available for comparisons in databanks; however, sequences corresponding to RABVs from southern Brazil are not readily available in databanks. The current study contributes to the availability of sequences in the public databanks, providing additional resources for a better understanding of the occurrence of rabies in the region.

The findings reported here are expected to contribute to the understanding of the biology of the virus in the region and its interactions with the natural host $D$. rotundus. Eventually, such studies may be expected to contribute to decreases in the numbers of cattle lost due to rabies. It is likely that different $D$. rotundus colonies or clones segregated over time within the sampled region; this might have led to adaptation of the best suited viral sublineages.

\section{Conclusion}

Two genetic sublineages of rabies virus (RABV), $1 \mathrm{~A}$ and $1 \mathrm{~B}$, both associated with the vampire bat $D$. rotundus as their natural host, were identified during the period of sampling of this study (from 2012 to 2015). In the state of RS, sublineages $1 \mathrm{~A}$ and $1 \mathrm{~B}$ were detected with a predominance (37 out of 59 isolates) of sublineage $1 \mathrm{~A}$; cocirculation was suggested by the identification of the sublineages in two municipalities. In the state of SC, circulation of sublineage $1 \mathrm{~B}$ only was detected.

Acknowledgements We would like to thank the government funding. This study was supported by Health State Secretary of São Paulo. Part of this work was supported by FINEP Project Number 1.10.0783.00. $\mathrm{PMR}$ is a CNPq $1 \mathrm{~A}$ research fellow.

Author contributions MES, LLA, JCAR, JCF, SDT and HBCRB conceived and designed the experiments; MESF and ANFG performed practical experiments; MESF, PCJr., JGCK and RNO performed the analysis of sequences; MESF, PMR and HBCRB wrote the manuscript and prepared the figures. All authors reviewed and approved the final manuscript.

Funding Funding was provided by Health State Secretary of São Paulo (Grant No. IP01/15) and Part of this work was supported by FINEP project number 1.10.0783.00. PMR is a CNPq 1A research fellow (Grant No. FINEP Project Number 1.10.0783.00). 


\section{Compliance with ethical standards}

Conflict of interest The authors declare that they have no conflict of interest.

Ethical approval This work complies with Protocol No. 01/2015 issued by the Ethics Committee of the Pasteur Institute of São Paulo.

\section{References}

1. ICTV (International Committee on Taxonomy of Viruses) (2018) https://www.ictvonline.org Accessed 18 Mar 2019

2. Badrane H, Tordo $\mathrm{N}$ (2001) Host switching in lyssavirus history from the chiroptera to the carnivora orders. J Virol 75:8096-8104. https://doi.org/10.1128/JVI.75.17.8096-8104.2001

3. WHO (World Health Organization) (2014) Expert consultation on rabies. Second report. World Health Organization Technical Report Series 982, Geneva

4. SVS/MS (Secretaria de Vigilância Sanitária do Ministério da Saúde) (2014) https://portal.saude.gov.br/portal/saude Accessed 18 Mar 2014

5. Roehe PM et al (1987) Diagnostico Laboratorial da Raiva No Rio Grande do Sul. Revista Panamericana de Salud Pública/Pan American Journal of Public Health 102:464-475

6. Silva Neto AM, Rodrigues AR, Carvalho KCN (2012) Caracterização da raiva humana no Brasil no período de 2001-2011. Revista Educação em Saúde 1:44-56

7. Kobayashi Y, Sato G, Shoji Y, Sato T, Itou T, Cunha EM, Samara SI, Carvalho AA, Nociti DP, Ito FH, Sakai T (2005) Molecular epidemiological analysis of bat rabies viruses in Brazil. J Vet Med Sci 67:647-652. https://doi.org/10.1292/jvms.67.647

8. Kobayashi Y, Inoue N, Sato G, Itou T, Santos HP, Brito CJ, Gomes AA, Santos MF, Silva MV, Mota CS, Ito FH, Sakai T (2007) Phylogenetic characterization of rabies virus isolates from carnivora in Brazil. J Vet Med Sci 69:691-696. https://doi. org/10.1292/jvms.69.691

9. Dean DJ, Abelseth MK, Atanasiu P (1996) The fluorescent antibody test. In: Meslin FX, Kaplan MM, Koprowski H (eds) Laboratory techniques in rabies, 4th edn. World Health Organization, Geneva, pp 88-95

10. Mochizuki N, Kobayashi Y, Sato G, Hirano S, Itou T, Ito FH, Sakai T (2011) Determination and molecular analysis of the complete genome sequence of two wild-type rabies viruses isolated from a haematophagous bat and a frugivorous bat in Brazil. J Vet Med Sci 73(6):759-766. https://doi.org/10.1292/jvms.10-0238

11. Orciari LA, Niezgoda M, Hanlon CA, Shaddock JH, Sanderlin JH, Yager PA, Rupprecht CE (2001) Rapid clearance of SAG-2 rabies virus from dogs after oral vaccination. Vaccine 31:4511-4518

12. Hall TA (1999) BioEdit: a user-friendly biological sequence alignment editor and analysis program for Windows 95/98/NT. Nucleic Acids Symp Ser 41:95-98

13. Tamura K, Nei M (1993) Estimation of the number of nucleotide substitutions in the control region of mitochondrial DNA in humans and chimpanzees. Mol Biol Evol 10:512-526. https://doi. org/10.1093/oxfordjournals.molbev.a040023

14. Kumar S, Stecher G, Tamura K (2016) MEGA7: molecular evolutionary genetics analysis version 7.0 for bigger datasets. Mol Biol Evol 33:1870-1874. https://doi.org/10.1093/molbev/msw054
15. Oliveira RN, De Souza SP, Lobos RS, Castilho JG, Macedo CI, Carnieli P (2010) Rabies vírus in insectivorous bats: implications of the diversity of the nucleoprotein and glycoprotein genes for molecular epidemiology. Virology 405(2):352-360

16. Itou T, Fukayama T, Mochizuki N, Kobayashi Y, Deberaldini ER, Carvalho AA, Ito FH, Sakai T (2016) Molecular epidemiological tracing of a cattle rabies outbreak lasting less than a month in Rio Grande do Sul in southern Brazil. BMC Res Notes 9:87. https:// doi.org/10.1186/s13104-016-1898-5

17. Carnieli P Jr, Fahl WDO, Castilho JG, Oliveira RDN, Macedo CL, Durymanova E (2008) Characterization of Rabies vírus isolated from canids and identification of the main wild canid host in Northeastern Brazil. Virus Res 131(1):33-46

18. Castilho JG, Carnieli P Jr, Durymanova EA, Fahl Wde O, Oliveira Rde N, Macedo CI, da Rosa ES, Mantilla A, Carrieri ML, Kotait I (2010) Human rabies transmitted by vampire bats: antigenic and genetic characterization of rabies virus isolates from the Amazon region (Brazil and Ecuador). Virus Res 153(1):100-105. https:// doi.org/10.1016/j.virusres.2010.07.012

19. Vieira LFP, Brandao PE, Oliveira RN, Carnieli-Junior P, Chicarino CN, Galante AC, Carrieri ML, Kotait I, Pereira SRFG (2010) Molecular characterization of rabies virus isolated from Desmodus rotundus captured in Rio de Janeiro State. Arq Bras Med Vet Zootec 62(2):343-349

20. Guarino H, Castilho JG, Souto J, Oliveira RN, Carrieri ML, Kotait I (2013) Antigenic and genetic characterization of rabies virus isolates from Uruguay. Virus Res 173(2):415-420

21. Macedo CI, Carnieli P Jr, Fahl WO, Lima JYO, Oliveira RN, Achkar SM, Castilho JG, Carrieri ML, Kotait I (2010) Genetic characterization of rabies virus isolated from bovines and equines between 2007 and 2008, in the States of São Paulo and Minas Gerais. Rev Soc Bras Med Trop 43(2):116-120

22. Torres C, Lema C, Dohmen FG, Beltran F, Novaro L, Russo S, Freire MC, Velasco-Villa A, Mbayed VA, Cisterna DM (2014) Phylodynamics of vampire battransmittedrabies in Argentina. Mol Ecol 23(9):2340-2352. https://doi.org/10.1111/mec.12728

23. Bordignon J, Brasil-Dos-Anjos G, Bueno CR, Salvatiera-Oporto J, Dávila AM, Grisard EC, Zanetti CR (2005) Detection and characterization of rabies virus in Southern Brazil by PCR amplification and sequencing of the nucleoprotein gene. Arch Virol 150(4):695-708. https://doi.org/10.1007/s00705-004-0448-y

24. Kanitz FA, Kowalski AP, Batista HBCR, Carnieli P Jr, Oliveira RN, Weiblen IR, Flores EF (2014) Epidemiologia molecular de surto de raiva bovina na região central do Rio Grande do Sul, 2012. Ciência Rural, Santa Maria 44:834-840. https://doi. org/10.1590/S0103-84782014000500012

25. Cargnelutti JF, Quadros JM, Martins M, Batista HBCR, Weiblen R, Flores EF (2017) Glycoprotein-G-gene-based molecular and phylogenetic analysis of rabies viruses associated with a large outbreak of bovine rabies in southern Brazil. Arch Virol 162(12):3697-3704. https://doi.org/10.1007/s00705-017-3533-8

Publisher's Note Springer Nature remains neutral with regard to jurisdictional claims in published maps and institutional affiliations. 